\title{
PENATAAN PERMUKIMAN INFORMAL KOTA MENJADI DAERAH TUJUAN WISATA STUDI KASUS: KAMPUNG TRIDI, MALANG
}

\author{
Anggoro Cipto Ismoyo ${ }^{1}$ \\ ${ }^{1}$ Universitas Telkom, email: anggoroismoyo@telkomuniversity.ac.id
}

\begin{abstract}
Kampung Tridi is the name for an informal settlement in the city of Malang which has been designated as a tourist destination. The adjustment of the function from just a residential area to a tourism area will lead to efforts to adjust the requirements as a tourist destination. This study aims to: 1). Revealing about the concept of informal settlements arrangement into tourism destinations, 2). Identify and describe the application of the concept of settlement arrangement into a tourist destination based on its constituent components and tourism activities that occur in it, and 3). Assessing the success of informal settlement arrangement into tourist destinations based on the level of visits and their impact on the community. The research method used is descriptive and qualitative in nature, with data collection strategies through field observations and interviews, and analysis based on literature review. The results showed that the concept of settlement arrangement was initiated by making a three-dimensional mural of the physical setting of the settlement, then it is developed by providing several facilities and tourism attractions to support tourism activities. Based on the high level of visits, as well as the positive social and economic impacts received by the community, Kampung Tridi can be assessed as a successful strategy for informal settlement arrangement with a community-based tourism approach.
\end{abstract}

\section{Keywords: Kampung Tridi, informal settlement, concept, arrangement, tourist destination}

\begin{abstract}
Abstrak
Kampung Tridi merupakan sebutan bagi suatu pemukiman informal di kota Malang yang telah ditata menjadi daerah tujuan wisata. Penyesuaian fungsi dari sekadar kawasan bermukim menjadi kawasan pariwisata akan membawa pada upaya penyesuaian persyaratan sebagai tujuan wisata. Tujuan dari penelitian ini untuk: 1). Mengungkap tentang konsep penataan permukiman informal menjadi daerah tujuan pariwisata, 2). Mengidentifikasi dan mendeskripsikan penerapan konsep penataan permukiman menjadi daerah tujuan wisata berdasarkan komponen pembentuk serta aktivitas wisata yang dilakukan di dalamnya, serta 3). Menilai keberhasilan penataan permukiman informal menjadi daerah tujuan wisata berdasarkan tingkat kunjungan serta dampaknya bagi warga masyarakat. Penelitian ini menggunakan metode deskriptif dan bersifat kualitatif, dengan strategi pengumpulan data dari observasi lapangan dan wawancara, berikut analisis berdasar tinjauan pustaka. Hasil penelitian menunjukkan bahwa konsep penataan permukiman diawali melalui pembuatan mural gambar tiga dimensi pada seting fisik permukiman, kemudian dikembangkan dengan penyediaan beberapa sarana dan daya tarik wisata untuk mendukung kegiatan berwisata. Berdasarkan tingkat kunjungan, serta dampak positif secara sosial dan ekonomi yang diterima masyarakat, maka Kampung Tridi dapat dinilai sebagai strategi penataan permukiman informal dengan pendekatan kepariwisataan berbasis masyarakat yang berhasil.
\end{abstract}

Kata-kunci : Kampung Tridi, permukiman informal, konsep, penataan, daerah tujuan wisata

\section{Pendahuluan}

Pemukiman penduduk spontan atau liar pada mulanya merupakan dampak dari urbanisasi, yangmana pendatang akan menempati tanah atau lahan kosong yang pemiliknya tidak diketahui, kemudian terjadi pembiaran, lalu secara lambat laun akan menjadi perumahan yang padat dan tidak terkendali. Pemilikan rumah di lahan tersebut juga dapat berganti-ganti pemilikan, sehingga sulit terjadi pengusiran (Pasya, 2012). Upaya penataan dan pengendalian terhadap pertumbuhan permukiman liar dan kumuh, tidak jarang ditempuh pemerintah dengan cara penggusuran hingga rencana relokasi. Pada praktiknya, upaya relokasi tidak semudah yang direncanakan dan dilaksanakan. Keadaan demikian terjadi karena pada permukiman 
yang telah terbentuk dalam kurun waktu lama, akan membentuk kebiasaan, kesepakatan, bahkan kekuatan sosial serta budaya tersendiri bagi para penghuninya. Sebagaimana dinyatakan Budiharjo (2006) permukiman sebagai wadah kehidupan manusia bukan hanya menyangkut aspek fisik dan teknis saja, tetapi juga aspek-aspek sosial, ekonomi, dan budaya dari para penghuninya.

Alternatif penanganan penataan permukiman liar selain penggusuran permukiman adalah dengan jalan perbaikan. Perbaikan permukiman memiliki dampak yang minim terhadap kehidupan orang-orang dan pada jaringan rentan pendukung bersama dalam masyarakat miskin. Perbaikan permukiman biasanya melibatkan beberapa perubahan dalam tatanan masyarakat yang telah eksis untuk penyediaan fasilitas infrastruktur yang lebih baik. Namun perubahan-perubahan ini tidak perlu drastis, kecuali masyarakat memilih untuk membangun kembali permukiman mereka dari nol, dan mulai dari awal dengan rencana baru, infrastruktur dan perumahan. Masyarakat bisa menemukan beberapa cara diplomatis untuk mengakomodasi kebutuhan orang yang rumahnya perlu dihancurkan atau dipindahkan dengan memberikan jalan untuk perbaikan. Terdapat banyak pilihan, dan sifat dari proyek perbaikan tergantung pada prioritas dan sumber daya dari orang-orang yang hidup dalam masyarakat tersebut UNESCAP dan UN-HABITAT, 2008).

Satu dari upaya peningkatan ekonomi sekaligus perbaikan kualitas lingkungan adalah melalui pendekatan pariwisata. Sektor pariwisata memiliki peran yang sangat penting untuk dapat mengurangi kemiskinan (Hall, 2007). Hal tersebut karena karakteristik pariwisata yang dapat mengurangi masyarakat miskin yaitu dengan wisatawan yang datang ketempat tujuan membuka peluang bagi penduduk lokal untuk memasarkan berbagai komoditi dan pelayanan, membuka peluang bagi upaya untuk mendiversikan ekonomi lokal yang dapat menyentuh kawasan-kawasan marginal, membuka peluang bagi usaha-usaha ekonomi padat karya yang berskala kecil dan menengah yang terjangkau oleh kaum miskin, tidak hanya tergantung pada modal, namun juga terkait dengan modal budaya (cultural capital) dan alam (natural capital) yang tidak jarang merupakan aset yang dimiliki oleh masyarakat miskin (Antariksa, 2011).

Kampung Tridi sebelumnya merupakan permukiman liar di kawasan kota Malang yang muncul dan berkembang pada area bantaran sungai Brantas, serta berada di bawah jembatan jalur kereta api. Sebagaimana permukiman informal pada umumnya, maka kondisi lingkungan yang relatif tidak teratur, berikut minimnya sarana prasarana pendukung lingkungan terbangun, memiliki tantangan tersendiri untuk ditata menjadi kawasan tujuan wisata. Penyesuaian ataupun perubahan yang dilakukan pada seting permukiman informal menjadi daerah tujuan wisata tentu menuntut kreativitas, kemampuan teknis, pembiayaan, maupun pengelolaannya. Hal tersebut menarik untuk diteliti dan diungkap, utamanya tentang konsep penataan dan penerapannya, mengingat segenap keterbatasan seting fisik dan sumberdaya yang tersedia. Tujuan dari penelitian ini adalah mengkaji penerapan konsep penataan kawasan permukiman informal kota menjadi daerah tujuan wisata, serta menilai sejauh mana tingkat keberhasilannya secara kualitatif berdasarkan tingkat kunjungan serta dampak sosial dan ekonominya.

\section{Tinjauan Pustaka}

\section{Pengertian dan Karakteristik Kampung Kota}

Kampung merupakan istilah yang sulit didefinisikan sebagai unit-unit administratif. Kampung kota dapat berupa unit lingkungan atau unit pemukiman atau unit kecamatan atau "kelurahan". Kampung kota di Indonesia mencakup aspek kehidupan multifaset. Di satu sisi, fungsinya mampu menyediakan perumahan yang terjangkau bagi mayoritas penduduk kota di mana kebanyakan dari mereka adalah orang-orang yang berpenghasilan menengah ke bawah. Di sisi lain, pada kenyataannya kualitas fisik yang buruk dan lacak dari layanan dasar yang memadai, kampung perkotaan diyakini untuk menyampaikan kegiatan informal yang lebih bersemangat dan kreatif (Sastrosasmito, 2009). Sebuah kampung di wilayah perkotaan memiliki karakteristik yang sering homogen dimana penduduk biasanya berasal dari desa pedesaan dan tinggal di daerah perkotaan serta mengubah aktivitas ekonomi penghuninya dari primer (pertanian dan ternak) menjadi pekerjaan formal-informal. Selain itu, masyarakat lokal memiliki sistem sosial, nilai sosial, dan hubungan keluarga sendiri. Modal sosial ini seringkali lebih penting daripada kualitas lingkungan sekitarnya karena memberi penghuninya kekuatan untuk mempertahankan diri yang disebut komunitas otonom (Funo, Yamamoto, dan Silas, 2002). Sebagai kesatuan integral kota, maka kampung merupakan salah satu komponen dalam pembentukan struktur kota, yaitu sebagai kawasan permukiman di dalam kota yang terbentuk tanpa perencanaan atau tumbuh sebelum perencanaan diterapkan (Nugroho, 2009). 
Jurnal Arsitektur AIJR - Vol 4 No 1 Mei 2021

e-ISSN 2685-1490; p-ISSN 2615-1472

\section{Pembangunan Kepariwisataan}

Wisata merupakan kegiatan perjalanan yang dilakukan oleh seseorang ataupun sekelompok orang dengan mengunjungi tempat tertentu untuk tujuan rekreasi, pengembangan pribadi, atau mempelajari keunikan daya tarik wisata yang dikunjungi, dalam rentang waktu sementara. Orang yang melakukan aktivitas wisata disebut wisatawan. Sementara itu, Pariwisata adalah berbagai macam kegiatan wisata dan didukung berbagai fasilitas serta layanan yang disediakan oleh masyarakat, pengusaha, Pemerintah, dan Pemerintah Daerah. Suatu pelaksanaan rencana pembangunan kepariwisataan dilakukan dengan memperhatikan keanekaragaman, keunikan, kekhasan budaya dan alam, serta kebutuhan manusia untuk berwisata (Undang-undang Republik Indonesia no. 10, 2009). Untuk keperluan perencanaan dan pengembangan kepariwisataan, perlu dibedakan antara jenis dan macam pariwisata satu dengan lainnya, sehingga dapat dikembangkan sesuai dengan diharapkan dari kepariwisataan tersebut (Suwena dan Wiyatmaja, 2017).

Dalam Undang-undang Republik Indonesia no. 10 tahun 2009 tentang Kepariwisataan, disebutkan bahwa Daerah Tujuan Wisata atau Destinasi Wisata adalah kawasan geografis yang berada dalam satu atau lebih wilayah administratif yang di dalamnya terdapat daya tarik wisata, fasilitas pariwisata, fasilitas umum, aksesibilitas, serta masyarakat yang saling terkait dan melengkapi terwujudnya kepariwisataan. Untuk mendukung keberadaan daerah tujuan wisata diperlukan unsur-unsur pokok yang harus diperhatian agar wisatawan bisa aman, tenang, dan nyaman ketika berkunjung. Adapun unsur-unsur pokok pendukung daerah tujuan wisata tersebut, antara lain: (i) Objek dan daya tarik wisata; (ii) Prasarana wisata; (iii) Sarana wisata; (iv) Tata laksana/infrastruktur, dan (v) Masyarakat/lingkungan. Suatu daerah tujuan wisata hendaknya memenuhi beberapa syarat, yakni ketersediaan: (i) sesuatu yang dapat dilihat (something to see); (ii) sesuatu yang dapat dilakukan (something to do); dan (iii) sesuatu yang dapat dibeli (something to buy). Dengan perkembangan spektrum pariwisata yang makin luas, maka Suwena dan Widyatmaja (2017) menambahkan dua syarat lain yakni: (iv) sesuatu yang dinikmati, yakni hal-hal yang memenuhi selera dan cita rasa wisatawan dalam arti luas; dan (v) sesuatu yang berkesan, sehingga mampu membuat wisatawan bertahan lebih lama, ataupun merangsang kunjungan ulang.

Pariwisata merupakan suatu gejala sosial yang sangat kompleks dan memiliki berbagai macam aspek penting yang menyangkut manusia seutuhnya. Aspek-aspek tersebut antara lain aspek sosiologis, psikologis, ekonomis, ekologis dan aspek-aspek lainnya. Aspek yang mendapat perhatian yang paling besar diantara sekian banyak aspek tersebut dan hampir merupakan aspek yang dianggap paling penting adalah aspek ekonomisnya (Yoeti, 1985). Pembangunan di sektor kepariwisataan perlu ditingkatkan dengan cara mendayagunakan dan mengembangkan berbagai sumber serta potensi kepariwisataan nasional maupun daerah, agar dapat menjadi kegiatan ekonomi yang dapat diandalkan dalam rangka memperbesar pendapatan asli daerah, memperluas serta memeratakan kesempatan usaha ataupun lapangan kerja utamanya bagi masyarakat setempat (Dimyati, 2003).

\section{Metode}

Penelitian ini menggunakan pendekatan deskriptif dan bersifat kualitatif. Pendekatan deskriptif dipilih untuk menggambarkan dan menjelaskan perubahan karakteristik visual dan fisik spasial yang terjadi untuk memenuhi tujuan wisata, yang ditujukan pada seting kawasan permukiman kota yang dipilih sebagai obyek kasus.

\section{Metode Pengumpulan Data}

Data yang diperlukan untuk proses penelitian ini pada prinsipnya terdiri dari dua jenis data, yakni:

1) Data primer, yang diperoleh dari proses observasi langsung di lapangan untuk mendapatkan informasi visual dengan jalan mendokumentasikan kondisi seting fisik kawasan, manusia, dan aktivitas yang terjadi di dalamnya. Selain cara pendokumentasian visual, wawancara dilakukan secara terstruktur dan bertujuan dengan pihak yang dinilai sesuai untuk tujuan penelitian, yang dilengkapi pula dengan wawancara secara terpilih, yakni ketua kelompok masyarakat, pengelola wisata, dan beberapa warga sekitar, untuk memperoleh kelengkapan informasi tambahan ataupun konfirmasi terhadap keterangan yang diberikan pada wawancara yang lain, serta;

2) Data sekunder, yang diperoleh dari dokumentasi visual, karya ilmiah, ataupun tulisan yang bersumber dari media cetak, internet, maupun sumber sejenis yang relevan dengan topik penelitian, terutama terkait dengan dengan Kampung Tridi. 


\section{Obyek dan Lokasi Penelitian}

Obyek dan lokasi penelitian ini merupakan kawasan permukiman yang telah dikenal sebagai Kampung Tridi. Secara kewilayahan permukiman tersebut terletak di Kelurahan Kesatrian, Kecamatan Blimbing, Kota Malang, pada Jalan Temenggungan Ledok, RT $1-4$, RW 12. Lokasi Kampung Tridi berseberangan dengan Kampung Warna-Warni Jodipan (KWJ) yang terletak di sisi Selatan, dan dibatasi oleh Sungai Brantas (ilustrasi pada Gambar 1)
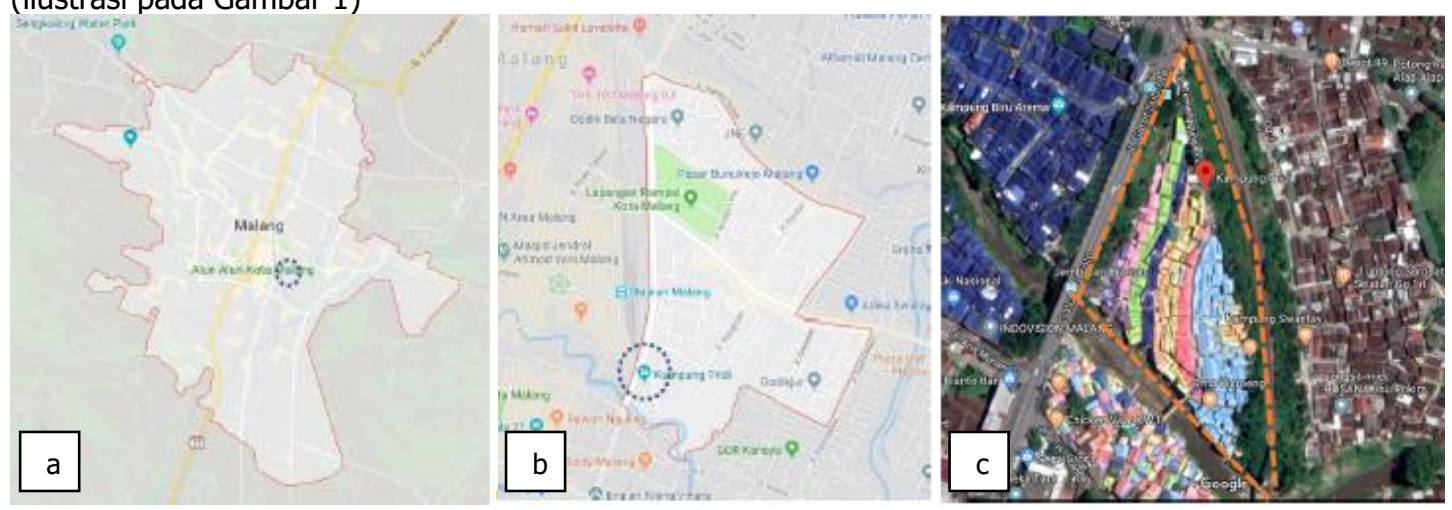

Gambar 1. Obyek Kasus Penelitian: (a) Peta legenda kota Malang, (b) Wilayah Kesatrian, dan (c) Kawasan Kampung

\section{Metode Analisis Data}

Tridi

Sebagaimana pendekatan penelitian yang digunakan, yakni bersifat kualitatif dan deskriptif, maka hasil observasi dan wawancara di lapangan maupun pengumpulan informasi sekunder, akan menjadi bahan untuk identifikasi hal-hal yang akan dianalisis secara deskriptif. Teknik analisis dan pembahasan dilakukan berdasarkan temuan tentang gagasan, penerapan konsep, dan identifikasi tentang karakter fisik dan ruang pada kawasan obyek penelitian yang terbentuk akibat tujuan pengupayaan menjadi destinasi wisata, disandingkan dengan kajian pustaka tentang penataan permukiman serta kepariwisataan, utamanya dalam kaitan dengan kriteria-kriteria pokok suatu daerah tujuan wisata serta daya tarik wisata yang dihadirkan. Pembahasan berikutnya dilakukan untuk menilai tingkat keberhasilan pendekatan pariwisata yang digunakan dalam penataan permukiman. Dengan demikian pembahasan penelitian ini akan menghasilkan jawaban pokok sesuai dengan tujuan penelitian, yakni tentang:

1. Konsep penataan permukiman liar menjadi Daerah Tujuan Wisata;

2. Penerapan konsep penataan dan kelayakannya melalui identifikasi karakteristik komponenkomponen pokok pembentuk Daerah Tujuan Wisata dan Kegiatan Wisata; dan

3. Penilaian keberhasilan penerapan penataan permukiman sebagai Daerah Tujuan Wisata berdasarkan kunjungan dan dampaknya terhadap warga permukiman

\section{Analisis dan Pembahasan}

\section{Sejarah dan Gagasan Pendorong Terbentuknya Kampung Tridi}

Kampung yang sekarang dikenal sebagai Kampung Tridi sebelumnya tidak terlalu dikenal oleh masyarakat kota Malang melainkan sebagai permukiman kumuh, kotor, bahkan rawan kejahatan dan kenakalan remaja. Sejarah terwujudnya Kampung Tridi tidak bisa dilepaskan dari keberadaan Kampung Warna-Warni Jodipan yang berada berseberangan di sebelah Selatan sungai Brantas (Gambar 2). Terinspirasi dari perubahan kondisi dan suasana permukiman yang berada di seberang selatannya, yakni permukiman di kelurahan Jodipan yang telah ditata menjadi Kampung Warna-Warni, maka ada seorang pemuda yang awalnya mencoba menuangkan gagasan lukisan bertema tiga dimensi pada beberapa bagian dinding di wilayah perkampungan. Ternyata hal tersebut menarik minat kunjungan dari warga luar kampung, mulai berdatangan untuk sekadar berfoto dengan latar gambar tiga dimensi yang dibuat. Berangkat dari kondisi tersebut, maka gagasan untuk menuangkan gambar tiga dimensi di beberapa titik permukiman warga semakin menguat untuk dilanjutkan sehingga merubah wajah dan suasana kampung yang sebelumnya kumuh menjadi menarik dan berpeluang menjadi daerah tujuan wisata. 

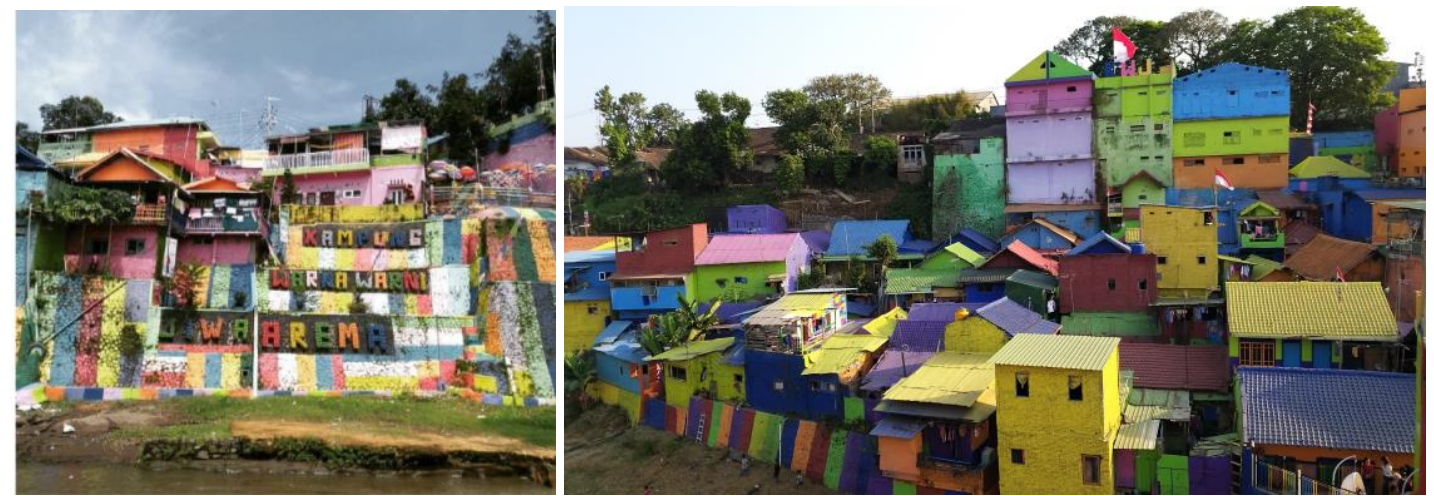

Gambar 2. Tampilan Kampung Warna-warni Jodipan (KWJ) yang Merupakan Hasil Penataan dan Peremajaan Kawasan Permukiman Jodipan Menjadi Inspirasi Terbentuknya Kampung Tridi

\section{Mural Tiga Dimensi sebagai Identitas dan Daya Tarik Kampung Tridi}

Disebut "Tridi" menunjuk pada akronim yang berasal dari Bahasa Inggris yakni "three d" yangmana "three" berati "tiga" dan " $\mathrm{d}$ " adalah singkatan dari "dimension". Istilah tersebut kemudian disesuaikan dengan pengucapan lokal untuk memudahkan dengan sebutan "Tridi". Penggunaan kata "Kampung" yang disandingkan dengan "Tridi" menjadi "Kampung Tridi" dilakukan untuk memudahkan pengenalan dan sebutan kawasan permukiman, sebagaimana permukiman di Jodipan yang kemudian disebut sebagai Kampung Warna-warni. Dengan demikian yang dimaksud Kampung Tridi secara sederhana dapat dikenali dengan permukiman ataupun perkampungan kota yang di dalam kawasannya terdapat lukisan atau gambar-gambar yang bersifat tiga dimensional. Kegiatan melukis pada permukaan dinding lazim dikenal dengan mural, dengan bahan utama cat tembok dan cat minyak. Secara umum karakteristik gambar tiga dimensi yang dimural diwujudkan dengan kondisi sebagai berikut (Gambar 3):

a) Gambar yang dilukis seolah keluar dari dinding atau permukaan bangunan

b) Gambar yang dilukis dengan perspektif tertentu sehingga memberikan kesan ruang tiga dimensi

c) Gambar yang dilukis pada permukaan bangunan ditujukan untuk menjadi latar belakang pengambilan foto terhadap obyek, sehingga memberikan kesan menyatu dengan obyek yang difoto
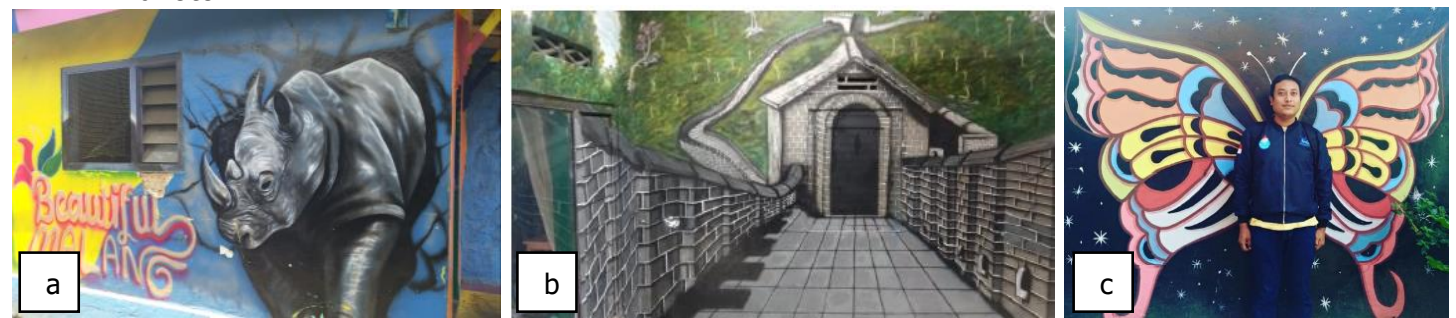

Gambar 3. Karakteristik Umum Perwujudan Mural Gambar Tiga Dimensi di Kampung Tridi: (a). Gambar berkesan muncul, (b). Gambar berkesan perspektif, dan (c). Gambar sebagai latarbelakang obyek

\section{Konsep Penataan Permukiman dan Pariwisata pada Kampung Tridi}

Merujuk pada latar belakang terwujudnya Kampung Tridi sebagai daerah tujuan wisata tersebut dapat terungkap bahwa konsep penataan permukiman yang diterapkan berangkat dari gagasan peremajaan kawasan permukiman melalui mural gambar tiga dimensional dengan konsekuensi untuk melakukan penyesuaian dengan perbaikan dan pembangunan yang diperlukan untuk mendukung kegiatan berwisata. Pada perkembangan berikutnya, daya tarik wisata pada Kampung Tridi dikembangkan dengan penambahan elemen-elemen dekoratif, serta wahana-wahana yang dapat digunakan oleh wisatawan untuk melakukan kegiatan wisata. Kegiatan penataan permukiman menjadi daerah tujuan wisata tersebut diawali, dilanjutkan, serta dikelola oleh masyarakat yang menghuni kawasan permukiman Kampung Tridi, dengan dukungan sponsor dari sebuah perusahaan cat untuk membantu kegiatan pengecatan dan pelukisan, serta dukungan dari pemerintah kota setempat dalam bentuk pembinaan dan pembentukan organisasi Kelompok Sadar Wisata (Pokdarwis). Dengan demikian dapat dinilai bahawa Kampung Tridi merupakan pelaksanaan dari konsep pariwisata berbasis masyarakat. 


\section{Karakteristik Perubahan Fisik dan Sosial Kampung Tridi sebagai Daerah Tujuan Wisata}

Penataan kawasan permukiman menjadi kawasan wisata membawa pada konsekuensi perubahan melalui penyesuaian-penyesuaian fisik lingkungan maupun sosial, sehingga layak menjadi suatu daerah tujuan wisata. Sebagaimana karakteristik suatu daerah tujuan wisata, maka hasil dari upaya penyesuaian yang diterapkan pada Kampung Tridi dapat diidentifikasi berdasarkan beberapa komponen pokok pendukung terbentuknya suatu daerah tujuan wisata, serta kegiatan kepariwisataan yang dapat diwadahi.

\section{Komponen-komponen Pokok pada Kampung Tridi sebagai Daerah Tujuan Wisata}

Komponen-komponen pokok yang dimiliki oleh Kampung Tridi sebagai Daerah Tujuan Wisata dapat didentifikasi sebagai berikut:

\section{Obyek dan Daya Tarik Wisata}

Obyek serta daya tarik (atraktor) wisata merupakan komponen pokok yang signifikan membuat suatu destinasi wisata dikunjungi oleh wisatawan. Obyek dan daya tarik wisata yang berada pada Kampung Tridi secara dominan berjenis buatan manusia, yakni berupa obyek mural yang sebagai daya tarik visual yang dapat dinikmati ataupun digunakan sebagai sarana latar belakang untuk berfoto. Selain obyek visual mural, pada Kampung Tridi juga dilengkapi dengan wahana-wahana untuk mendukung kegiatan berwisata, sebagaimana elemen-elemen dekoratif lingkungan, serta beberapa bangunan naungan dan jembatan dapat digunakan untuk aktivitas berfoto, berbincang, dan beristirahat. Obyek dan daya tarik wisata yang bersifat alamiah adalah pemandangan ke arah permukiman dan sungai brantas yang dapat dinikmati melalui wahana-wahana wisata yang dibuat dengan ketinggian tertentu sehingga pengunjung dapat memanfaatkannya untuk menikmati dan memandang ke arah pemukiman ataupun ke arah bantaran sungai.

2. Amenitas/Fasilitas/Sarana dan Prasarana

Amenitas merupakan segala macam fasilitas, prasarana dan sarana yang dapat dibutuhkan oleh wisatawan selama berada di lokasi wisata. Amenitas, fasilitas, sarana dan prasarana yang terdapat pada kawasan Kampung Tridi, antara lain: toilet umum, musala, tempat duduk dengan ataupun tanpa jaringan listrik, dan tempat sampah. Berdasarkan kondisi amenitas tersebut dapat diketahui bahwa beberapa fasilitas tersebut secara umum bersifat relatif mendasar, sederhana, dan ekonomis. Hal tersebut dikarenakan keterbatasan ruang dan ketersediaan sumberdaya, dan keharusan untuk menyesuaikan dengan eksisting kawasan yang fungsi dasarnya adalah permukiman. Amenitas berupa tempat penginapan belum tersedia pada kawasan Kampung Tridi, namun keperluan tersebut dapat dilayani oleh beberapa tempat penginapan yang berada relatif tidak jauh dari keberadaan Kampung Tridi, semisal di kawasan Tugu kota Malang yang berjarak dalam radius sekitar 1 (satu) kilometer.

\section{Aksesibilitas}

Secara geografis, Kampung Tridi terletak di area kota Malang yang relatif berdekatan dengan Tugu kota Malang, Kantor Walikota Malang dan DPRD kota Malang, serta Stasiun Kota Malang. Berdasarkan keberadaan bangunan perkantoran pusat pemerintahan serta fasilitas publik kota tersebut menunjukkan letaknya yang strategis, sehingga relatif mudah diakses. Untuk wisatawan yang datang dari luar kota atau luar daerah, dapat mencapai Kampung Tridi melalui moda transportasi Kereta Api, yangmana jarak stasiun ke lokasi Kampung Tridi berkisar 700 meter, kemudian dapat ditempuh dengan berjalan kaki yangmana memakan waktu sekitar 8 (delapan) menit. Bagi wisatawan yang berasal dari kota Malang dan sekitarnya dapat mencapai Kampung Tridi menggunakan transportasi publik via Mikrolet dengan jalur berkode ABG, AMG, AJG, MT, AL, MM, dan ADL, serta via Ojek Online maupun Becak.

\section{Pelayanan Tambahan}

Pelayanan tambahan yang berasal dari dukungan pemerintah untuk menunjang kepariwisataan di Kampung Tridi dilakukan dengan perbaikan dan pembangunan sarana jalan yang layak, yakni jalan lingkungan permukiman. Pemerintah kota juga telah membentuk Pokdarwis Kampung Tridi untuk memudahkan komunikasi maupun pembinaan kepariwisataan. Pelayanan tambahan yang diberikan warga Kampung Tridi sebagai bagian dari penyelenggara dan pengelola wisata dilakukan dengan memberikan suvenir sebagai tanda masuk berupa gantungan kunci yang memberi identitas Kampung Tridi. Meskipun relatif sederhana, upaya tersebut dapat dinilai sebagai bentuk keramahan kepada pengunjung agar merasa nyaman sekaligus mendapatkan sesuatu untuk diingat atau dikenang dari berkunjung ke Kampung Tridi. 
Jurnal Arsitektur AIJR - Vol 4 No 1 Mei 2021

e-ISSN 2685-1490; p-ISSN 2615-1472

\section{Kegiatan Wisata pada Kampung Tridi}

Setidaknya terdapat tiga kegiatan utama yang menjadikan kebutuhan berwisata, yakni sesuatu untuk dilihat (something to see), dilakukan (something to do), dan dibeli (something to buy). Pada seting Kampung Tridi sebagai daerah tujuan wisata, maka beberapa kegiatan wisatawan berdasarkan tujuannya yang dapat disediakan antara lain sebagai berikut:

\section{Sesuatu yang dapat dilihat (something to see)}

Kampung Tridi memiliki keunikan berdasarkan jenis wisata buatan, dengan obyek visual melalui ragam warna, lukisan tiga dimensi, serta wahana-wahana wisata pelengkapnya. Wisatawan dapat menikmati pemandangan buatan berupa gambar-gambar mural pada dinding-dinding luar rumah dan permukaan di lingkungan fisik permukiman, ataupun komposisi pewarnaan pada permukiman, elemenelemen dekoratif, wahana-wahana wisata serta suasana semarak Kampung Tridi oleh pewarnaan warna-warni (Gambar 4).

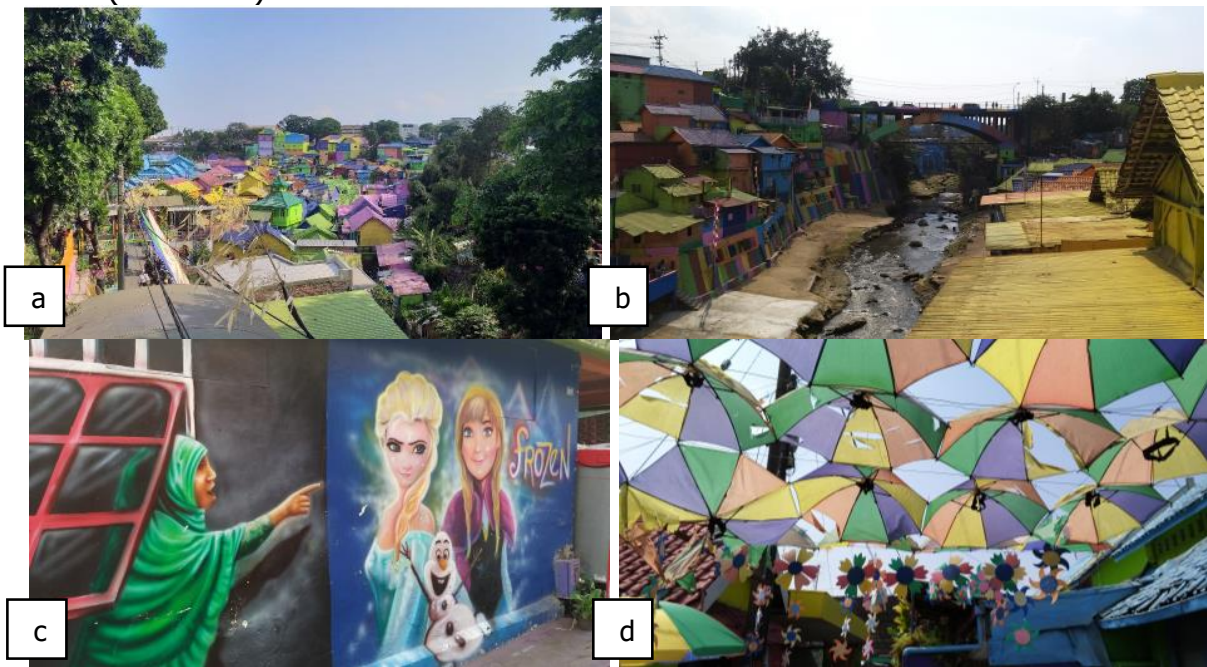

Gambar 4 (a) Pemandangan Permukiman Kampung Tridi; (b) Pemandangan Tepi Sungai Brantas; (c) Pemandangan dari Mural; dan (d) Pemandangan Elemen Daya Tarik berupa Dekoratif Lingkungan

\section{Sesuatu yang dapat dilakukan (something to do)}

Kampung Tridi memberikan kesempatan bagi para pengunjung yang ingin mengeksplorasi lingkungan kawasan permukiman, berfoto, swafoto, memfoto pemandangan, ataupun sekadar duduk berbincang dan menikmati pemandangan (Gambar 5).

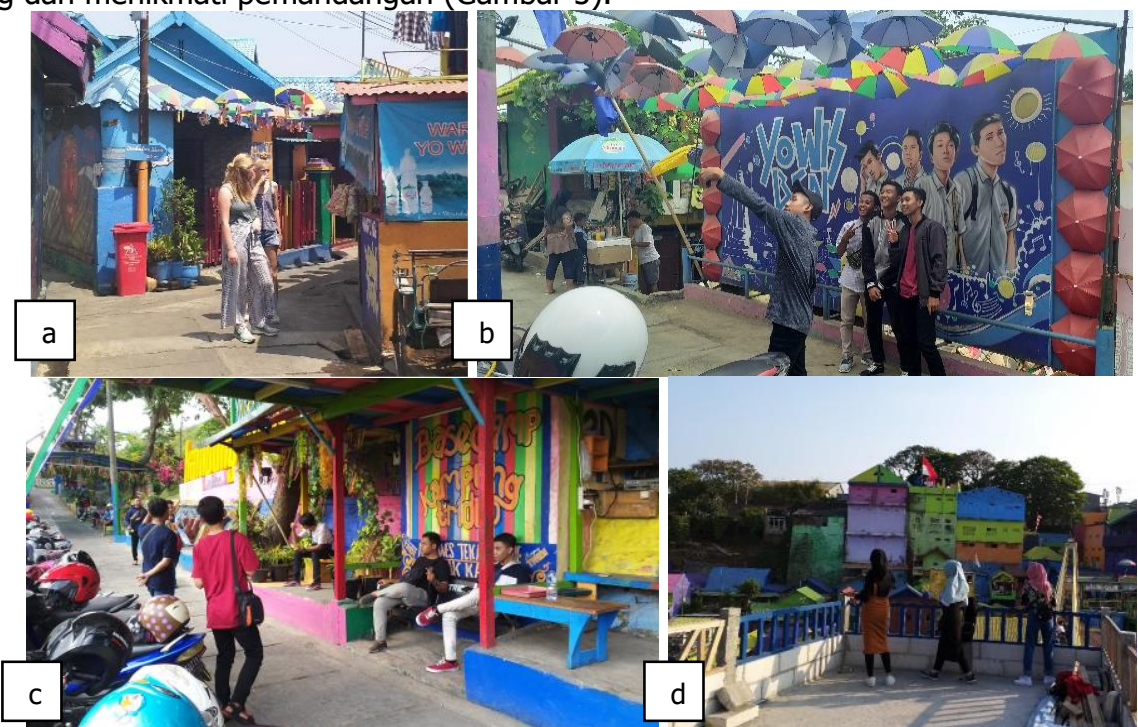

Gambar 5. Tipikal kegiatan wisata di Kampung Tridi: (a) Kegiatan mengeksplorasi lingkungan (b) Kegiatan berfoto dengan latarbelakang mural; (c) Kegiatan duduk dan berbincang; dan (d) Kegiatan menikmati pemandangan 
Jurnal Arsitektur AIJR - Vol 4 No 1 Mei 2021

e-ISSN 2685-1490; p-ISSN 2615-1472

\section{Sesuatu yang dapat dibeli (something to buy)}

Pada Kampung Tridi belum terdapat suatu toko yang menyediakan suvenir secara khas terkait Kampung Tridi. Namun demikian pada seting Kampung Tridi terdapat beberapa warung yang menyediakan makanan maupun minuman, toko kelontong, toko mainan, hingga pedagang makanan ringan keliling (Gambar 6).

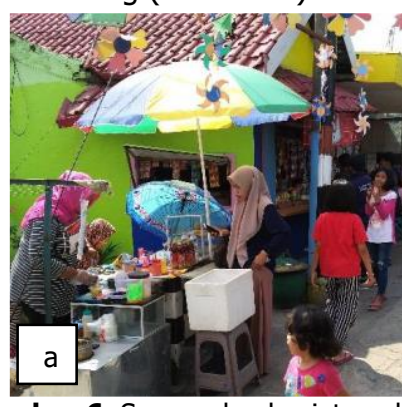

Gambar 6. Sarana dan kegiatan ekonon

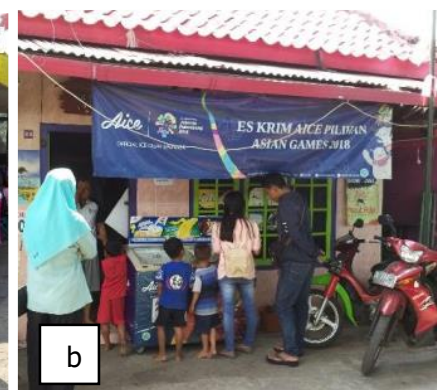

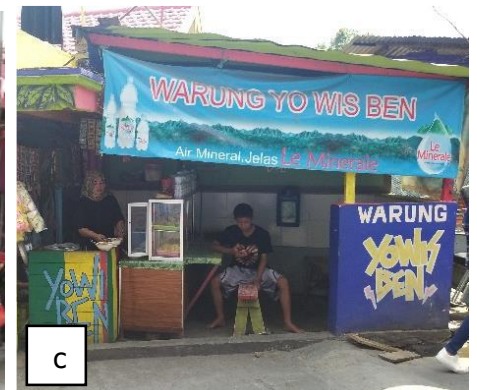

C

Keberadaan sesuatu yang dapat dibeli yang relatif terbatas tersebut disebabkan oleh eksisting area kawasan permukiman yang relatif terbatas, bahkan beberapa warung dan toko merupakan usaha yang telah dijalankan warga sebelum terbentuk Kampung Tridi.

\section{Kegiatan Warga Masyarakat terhadap Pengelolaan Kampung Tridi}

Pada proses berjalannya waktu, pengelolaan dan pengambangan Kampung Tridi dilakukan berdasarkan prinsip pengembangan berbasis partisipasi masyarakat. Eksekusi usulan perbaikan ataupun pengembangan obyek dan daya tarik (atraktor) wisata sebagaimana pengecatan, pelukisan, penambahan fasilitas ataupun wahana dilakukan secara gotong-royong (Gambar 7).

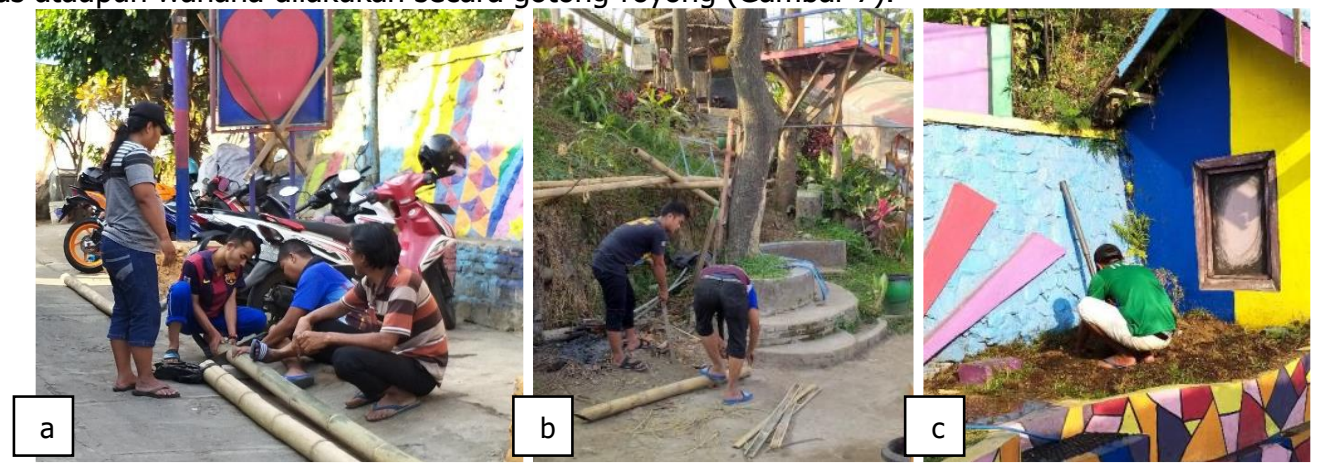

Gambar 7. Kegiatan warga dalam upaya perbaikan dan pengembangan Kampung Tridi: (a) Kegiatan koordinasi (b) Kegiatan pembuatan wahana; dan (c) Kegiatan pembersihan dan peremajaan pada lansekap

Beberapa upaya yang dilakukan warga masyarakat untuk meningkatkan dan mempertahankan daya tarik wisata Kampung Tridi antara lain:

1) Penambahan gambar-gambar tiga dimensi

2) Penambahan wahana, berupa elemen-elemen dekoratif, ruang-ruang maupun bangunan relatif sederhana di area yang diputuskan bersama untuk bisa dibangun, yang diharapkan digunakan para pengunjung (wisatawan) untuk berswafoto ataupun berfoto bersama

3) Pengecatan ulang, yang dijadwalkan sekitar 6 (enam) bulan sekali

4) Penggantian gambar, pada beberapa titik (spot) area

5) Menambah dan/atau memperbaiki fasilitas umum wisata, sebagaimana toilet-toilet, perawatan musala, dan sebagainya

Usaha-usaha tersebut dilakukan berdasarkan koordinasi, usulan, dan kesepakatan melalui pertemuan berkala setiap hari senin malam. Pengelolaan terhadap pembangunan dan pendapatan yang diperoleh dari operasional wahanawahana ataupun fasilitas-fasilitas yang ada di Kampung Tridi juga diupayakan oleh warga secara transparan dan adil, dari dan bagi warga kampung Tridi. Sebagai contoh pembagian tugas tersebut semisal apabila telah diputuskan membangun sebuah wahana wisata, maka diutamakan kaum laki-laki yang ikut bekerja akan mendapatkan bagian upah penghasilan dari parkir. 
Sementara umumnya untuk kaum ibu-ibu atau wanita bertugas untuk kebersihan dan pembuatan suvenir yang diberikan saat pengunjung mengisi buku tamu kunjungan.

\section{Keberhasilan Kampung Tridi sebagai Daerah Tujuan Wisata}

Kampung Tridi dapat dinilai sebagai strategi penanganan permukiman informal yang kumuh dengan pendekatan kepariwisataan yang berhasil, yang dapat dibuktikan dari tingkat kunjungan wisatawan dan dampak secara sosial maupun ekonomi yang dirasakan oleh masyarakat.

\section{Tingkat Kunjungan Wisatawan}

Menurut catatan tentang jumlah kunjungan wisatawan pada Kampung Tridi, dapat diketahui bahwa para wisatawan yang berkunjung tidak hanya berasal dari kawasan kota Malang dan sekitarnya, namun juga dari luar kota, luar provinsi, bahkan mancanegara. Tingkat kunjungan wisatawan tersebut relatif beragam, namun dapat dinilai relatif meningkat saat akhir pekan dan hari libur, dengan kunjungan per hari dapat mencapai 200 orang. Kondisi kunjungan tersebut menunjukkan bahwa Kampung Tridi sebagai daerah tujuan wisata dinilai memiliki keunikan daya tarik yang dihadirkan, sehingga berhasil mengundang para wisatawan, tidak hanya lokal bahkan mancanegara.

\section{Dampak Sosial dan Ekonomi Warga Masyarakat}

Penataan permukiman bantaran Sungai Brantas yang sebelumnya kumuh menjadi Kampung Tridi sebagai daerah tujuan wisata membawa dampak positif, tidak hanya bagi kondisi lingkungan terbangun namun juga secara sosial dan ekonomi. Beberapa dampak positif tersebut antara lain:

a) Merubah kondisi fisik kawasan yang sebelumnya kumuh, kotor dan tidak teratur, menjadi bersih, indah dan lebih rapi, serta merubah citra (image) kawasan permukiman yang dulu dikesankan kawasan pelaku kejahatan, menjadi kawasan untuk berwisata;

b) Memberikan lapangan pekerjaan bagi warga. Tidak kurang dari 27 pemuda warga Kampung Tridi diberdayakan untuk pengelolaan fasilitas dan wahana wisata, antara lain pelayanan tiket masuk dan parkir bagi pengunjung;

c) Memperkuat kebersamaan warga dengan bergotong royong dalam pengelolaan dan pengembangan Kampung Tridi. Hal tersebut sebagaimana perbaikan dan pembangunan sarana maupun prasarana lingkungan yang masih diperlukan, termasuk perbaikan toilet, bagian dari rumah warga, ataupun pembangunan wahana wisata yang belum ada. Proses tersebut dilakukan melalui pertemuan dan musyawarah warga, menanggapi usulan yang masuk, lalu mengalokasikan sebagian pendapatan untuk kebutuhan pembangunan tersebut;

d) Memberikan pembebasan iuran kematian dan pembagian bahan kebutuhan pokok bagi warga yangmana pendanaannya diambilkan dari sebagian hasil pendapatan kunjungan wisata; dan,

e) Berdirinya usaha-usaha yang menyediakan makanan dan minuman di kawasan Kampung Tridi, sehingga membawa dampak pada upaya kemandirian ekonomi warganya.

\section{Kesimpulan dan Saran}

Kampung Tridi merupakan suatu sebutan bagi kawasan permukiman di kota Malang yang sebelumnya merupakan permukiman informal baik dalam pengertian liar dan kumuh, kemudian ditata menjadi darah tujuan wisata di perkotaan (urban). Dari hasil penelitian ini dapat dikemukakan temuan-temuan sebagai berikut:

1. Konsep penataan permukiman informal yang diterapkan pada Kampung Tridi menggunakan strategi perbaikan, yakni peremajaan kawasan dengan pendekatan pariwisata berbasis masyarakat (community based tourism)

2. Penerapan konsep penataan pada Kampung Tridi dilakukan untuk memenuhi kelayakan sebagai daerah tujuan wisata dengan pembuatan mural-mural trimata (3D), pembangunan beberapa fasilitas dasar pendukung serta wahana wisata pada seting fisik kawasan, kemudian melakukan pengelolaan terhadapnya, sehingga pengunjung dapat melakukan kegiatan wisata di dalamnya

3. Kampung Tridi dinilai berhasil sebagai daerah tujuan wisata, yangmana keberhasilan tersebut bukan hanya berupa tertatanya lingkungan fisik kawasan, namun dapat ditinjau dari tingkat kunjungan wisatawan yang relatif tinggi, serta memberikan dampak positif secara sosial maupun ekonomi dari pengelolaan pariwisata, bagi warga yang menghuninya

Secara umum, penelitian ini dapat menjadi penelitian pendahuluan untuk dilanjutkan dengan topik serupa dengan lokus penelitian yang berbeda, guna mendapatkan perbandingan karakteristik, hingga konsep dan strategi penataan permukiman informal di perkotaan. Berdasarkan karakteristik, strategi, serta aspek-aspek fisik-spasial maupun non fisik yang dikaji tersebut kemudian dapat disusun suatu konsep yang 
Jurnal Arsitektur AIJR - Vol 4 No 1 Mei 2021

e-ISSN 2685-1490; p-ISSN 2615-1472

relatif komprehensif tentang model penataan kawasan permukiman informal kota, serta bahan referensi bagi pelaksanaan pembangunan yang berkelanjutan.

\section{Daftar Pustaka}

Anonim. (2009).Undang-Undang Republik Indonesia No. 10 tahun 2009 tentang Kepariwisataan, 3 - 4

Antariksa, B. (2011). Peluang dan Tantangan Pengembangan Kepariwisataan di Indonesia. Makalah Sosialisasi dan Gerakan Sadar Wisata. Pusat Penelitian dan Pengembangan Kepariwisataan Kementrian Kebudayaan dan Pariwisata Birin. Solok, hal. 3

Arisani, R. E., Ali, A., dan Fattah, V. Y.(2017). Revitalisasi Kawasan Permukiman pada Aktivitas Perekonomian Masyarakat di Bantaran Sungai Palu. E Journal Katalogis, Volume 5 Nomor 10, hal.130

Budihardjo, E. (2006). Sejumlah Masalah Permukiman Kota. Penerbit Alumni, Bandung, 61-67

Dimyanti, A. (2003). Usaha Pariwisata. Jakarta, hal. 87

Funo, S., Yamamoto, N., \& Silas, J. (2002) Typology of Kampung Houses and Their Transformation Process a Study on Urban Tissues of Indonesian City. Journal of Asian Architecture and Building Engineering, 1(2), 193-200

Hall, M. (2007). Pro-poor Tourism: Who Benefits? Prespectives on Tourism and Poverty Reduction. Channel View Publications, Canada, hal.10

Nugroho, A. C. (2009). Kampung Kota sebagai Sebuah Titik Tolak dalam membentuk Urbanitas dan Ruang Kota Berkelanjutan. Jurnal Rekayasa, Vol. 13 No.3, hal. 212

Pasya, G. K., (2012). Pemukiman Penduduk Perkotaan. GEA, Jurnal Pendidikan Geografi, Volume 12, Nomor 2, 61-70

Sastrosasmito, S. (2009). Compact Kampungs; Formal and Informal Integration in The Context of Urban Settlement of Yogyakarta, Indonesia. Journal of Habitat Engineering, 1(1), $119-134$

Suwena, I. K. dan Widyatmaja, I. G. N. (2017). Pengetahuan Dasar Ilmu Pariwisata. Pustaka Larasan, Bali, 19-22

UNESCAP dan UN-HABITAT (2008). Panduan Ringkas untuk Pembuat Kebijakan 2. Perumahan bagi Kaum Miskin di Kotakota Asia: Perumahan untuk MBR. Memberi Tempat yang Layak bagi Kaum Miskin Kota, Bangkok dan Nairobi, 4-13

Yoeti, O.A. (1985). Pemasaran Pariwisata. Angkasa. Bandung, hal. 56 